\title{
UJI EFEKTIVITAS GEL EKSTRAK ETANOL DAUN BINAHONG (Anredera cordifolia) SEBAGAI PENYEMBUHAN LUKA INSISI PADA TIKUS WISTAR JANTAN
}

\author{
1| Nurhikma Awaluddin, 2| Nurfiddin Farid, 3| Nurjannah Bachri \\ Email : hykma.awaluddin@gmail.com
}

\begin{abstract}
The effectiveness test of Binahong Leaf (Anredera cordifolia) ethanol extract gel as an incision wound healing in male Wistar rats by Nurhikma Awaluddin and Nurfiddin Farid. Injuries are structural or physiological integument disorders that require a normal or abnormal tissue repair response. An incisor wound is a wound caused by a tool that has a sharp tip and hits the skin layer. The purpose of this study was to determine the effectiveness of binahong leaf ethanol extract gel on incision wound diameter and wound healing time in male Wistar rats. The method used is experimental laboratory. The incision wound was observed for 14 days. Observations consisted of changes in wound length and duration of healing. The incision wound is characterized by tearing of the epidermal tissue $2 \mathrm{~cm}$ long. Binahong leaf extract gel preparation test was given to the incision wound of male Wistar rats by observing the formation of maturation, the time of wound closure. For administration of extracts with a concentration of $2 \%$ for tenth days at a concentration of $10 \%$, the wound closure occurred on the ninth day and at a concentration of $15 \%$ occurred on the eighth day. Observation of wound healing is characterized by the occurrence of complete closure of the wound on the skin, which begins with inflammation which is then followed by a process of proliferation and maturation or remodeling. The treatment of positive control using bioplastone preparation experienced faster wound closure compared to the other four formulas. The results of the ANOVA statistical analysis using SPSS, the relationship between formula and speed of closed wounds are 100\%, where Fcount> Ftable at the 5\% and 1\% confidence levels, this means that there is a difference in wound healing time of $100 \%$ which is very different / very significant from the use of each. each formula. Binahong leaf ethanol extract gel formula is effective in healing cuts in male Wistar rats with healing time less than 14 days.
\end{abstract}

ARTICLE INFO

\section{Keywords:}

Incision wound; Binahong leaf;

Extract; Gel

\section{Pendahuluan}

DOI:

$\underline{10.24252 / k e s e h a t a n . v 13 i 2 .}$

Popularitas tumbuhan obat atau herbal semakin meluas. Berbagai jenis produk terus bermunculan dalam bentuk herba medicine (obat herbal). Sebagian besar tanaman herbal ada disekitar kita. Petunjuk tentang kemungkinan adanya potensi bahan alam yang dapat berkhasiat sebagai obat.

Indonesia memiliki keanekaragamaan tanaman berkhasiat sebagai obat, salah satunya adalah binahong (Anredera Cordifolia) seluruh bagian tanaman menjalar ini berkhasiat mulai dari akar, batang dan daunnya. Secara empiris, tanaman binahong memiliki beberapa khasiat di antaranya, mempercepat pemulihan kesehatan setelah operasi, melahirkan, khitan, segala lukaluka dalam dan radang usus (1).

Tanaman binahong merupakan tanaman asli korea yang kemudian banyak ditanam dikawasan tropis lainnya, seperti Indonesia, tanamanan yang sangat bermanfaat sebagai salah satu bahan obat herbal ini banyak digunakan dalam pengobatan China. Di dalam daun Binahong, bagian utama yang digunakan dalam pengobatan herbal mengandung berbagai zat penting antara lain saponin, polifenol, alkaloid, minyak atsiri, dan asam oleanolik (2).

Pada penelitiaan tentang efektifitas salep ekstrak etanol daun binahong (Anredera Cordifolia) terhadap proses penyembuhan luka gores pada kelinci dilakukan uji fitokimia untuk melihat senyawa aktif dalam daun binahong. Hasil uji fitokimia tersebut menunjukkan intensitas warna tinggi adalah senyawa flavonoid, tanin dan saponin (1). dimana senyawa flavonoid yang terdapat dalam daun binahong dapat berperan langsung sebagai antibiotik dengan menganggu fungsi dari mikroorganisme seperti bakteri dan virus, tanin dapat mengkerutkan dinding sel atau membrane sel sehingga menganggu permeabilitas, sel tidak dapat melakukan aktivitas hidup sehingga pertumbuhannya terhambat atau bahkan mati sedangkan saponin mempunyai

1,2, 3 Universitas Megarezky, Indonesia 
kemampuan sebagai pembersih dan mampu memacu pembentukan kolagen pertama yang merupakan satu protein yang berperan dalam penyembuhan luka (1).

Luka adalah gangguan pada structural atau fisiologi integument yang membutuhkan respons perbaikan jaringan yang normal atau tidak normal. Semua luka dapat diklasifikasikan sebagai akut dan kronis. Luka akut merupakan proes penyembuhan tanpa komplikasi dalam kerangka waktu yang lazim, luka kronis adalah luka yang tidak sembuh dalam kerangka waktu yang diharapkan atau disertai dengan banyak komplikasi. Pada anak-anak, sebagian besar luka bersifat akut dan dapat dicegah (3). Sedangkan luka insisi dapat disebabkan kecelakaan maupun karena perlakuan medis, contohnya operasi. Pada saat terjadi luka, tubuh secara normal berusaha memperbaiki jaringan yang rusak dengan cara menimbulkan respon terhadap cedera yang dikarakteristik adanya bengkak, kemerahan, panas, nyeri, dan kerusakan fungsi (4).

Pada percobaan ini tikus wistar jantan digunakan sebagai hewan percobaan karena tikus wistar jantan merupakan hewan yang struktur mirip dengan manusia. Sediaan obat topikal untuk penyembuhan luka yang beredar dipasaran dapat ditemukan dalam bentuk krim, salep dan gel. Sediaan dalam bentuk gel lebih banyak digunakan karena bening, mudah mengering, membentuk lapisan film yang mudah dicuci dan memberikan rasa dingin di kulit (5).

Berdasarkan uraian diatas, maka dari itu dilakukan penelitian lebih lanjut tentang penggunaan Ekstrak Etanol daun Binahong (Anredera Cordifolia )yang dibuat dalam sediaan gel untuk melihat efek penyembuhan luka insisi pada hewan tikus wistar jantan. Dengan memperhatikan perubahan diameter luka insisi dan lama penyembuhannya luka.

Klasifikasi Tanaman (6).

Kingdom :Plantae

Divisi :Magnoliophyta (berbunga)

Kelas :Magnoliopsida

Ordo :Caryophyllales

Famili :Bassellacceae

Genus :Anredera

Spesies :Anredera Cordifolia (Ten) Steenis

Morfologi tanaman daun binahong. Binahong merupakan tumbuhan liana berumur panjang dengan panjang lebih dari $6 \mathrm{~m}$. akar tunggang berwarna coklat membentuk umbi dan lunak. Batang tidak berkayu tidak berair, bentuk silindris, saling membelit, permukaan halus, warna merah, bagian dalam padat. Binahong memiliki umbi yang terdapat di dalam tanah ketiak daun dengan bentuk tak beraturan dan bertekstur kasar. Daun tunggal, tersusun berseling, bentuk jantung, panjang 5-10 cm, lebar 3-7 cm, tekstur tipis lemas, ujung runcing, pangkal berlekuk, tepi rata, permukaan licin. Tangkai daun pendek. Bunga majemuk, berbentuk tandan, tangkai yang panjang. Muncul di ketiak daun. Daun kelopak berwarna hijau, 5 helai berlekatan. Daun mahkota berwarna putih krem, berjumlah 5 helai tidak berlekatan, panjang 0,5-1 cm, berbau harum (6).

Senyawa kimia yang terdapat dalam binahong adalah 3-hidroksi-30-horoleana-12, 18 dien-29oat, larragenin, etil ester, asam ursolat, binahong juga mengandung beberapa metabolit sekunder, yaitu jenis flavonoid, alkaloid, polifenol, triterpenoid dan saponin. Flavonoid yang terkandung dalam binahong dapat mengurangi inflamasi (Wahyuni Dkk, 2016). Kandungan kimia yang terdapat pada daun binahong antara lain flavonoid, asam oleanolik, asam askorbat, dan saponin. Berbagai kandungan kimia tersebut menyebabkan daun binahong dapat bersifat sebagai antibakteri, antivirus, antiinflamasi, analgesic dan antioksidan (7).

Kulit adalah sistem organ tubuh Kulit adalah sistem organ tubuh yang paling luas dan paling berat dari tubuh, kulit berfungsi untuk menjaga jaringan internal dari trauma, bahaya radiasi 
sinar ultra violet. temperature yang ekstrim, toksin dan bakteri (8).

Berat kulit secara keseluruhan sekitar 16\% berat tubuh (pada organ dewasa sekitar 2,7-3,6 kg) dan luasnya sekitar 1,5 sampai 1,9 m tebal kulit bervariasi yaitu antara 0,5 mm sampai $6 \mathrm{~mm}$ tergantung dari letak umur, dan jenis kelamin. Kulit tipis terdapat pada kelopak mata, penis dan kulit bagian medial lengan atas. Kulit yang tebal terletak pada telapak tangan, telapak kaki, punggung, bahu, dan bokong (8).

Kulit terdiri dari dari tiga lapisan yaitu ;

a) Epidermis

Kulit aria atau eoidermis adalah lapisan paling luar yang terdiri dari lapisan epitel gepeng unsur utamanya adalah sel-sel tanduk (keratinosit) dan sel melanosit. Lapisan epidermis tumbuh terus karena lapisan sel induk yang berada di lapisan bawah bermitosis terus, lapisan paling luar epidermis akan terkelupas atau tergugur. Epidermis tersusun oleh sel-sel epidermis terutama serat-serat kolagen dan sedikit elastis. Kulit ari (epidermis) terdiri dari beberapa lapis sel yaitu terdiri dari lima lapis yaitu:

1) Stratum corneum (lapisan tanduk)

2) Stratum lucidum (lapisan jernih)

3) Stratum gronulosum (lapisan berbutir-butir)

4) Stratum spinosim (lapisan Malpighi)

5) Stratum basale (lapisan basal)

b) lapisan dermis banyak pembuluh darah, folikel rambut, kelenjer sebaseae dan kelenjer keringat. Kualitas kulit tergantung banyak tidaknya derivate epidermis di dalam dermis. Secara keseluruhan lapisan dermis berfungsi sebagai struktur penunjang, pemberi nutrisi, faktor pertumbuhan dan perbaikan kulit. Dermis terbagi lagi atas :

1) pars persial (bagian atas dermis)

a. merupakan lapisan superficial yang terdiri atas jaringan vaskuler longgar.

b. Pas papiler kaya akan pleksus dan syaraf

2) Pas retikulasi (bagian bawah dermis)

a. Merupakan lapisan tebal yang lebih dalam, kurang vaskuler.

b. Bagian reticular ini lebih banyak mengandung jaringan kolagen, elastis dan retikulin.

c. Serat kolagen berfungsi sebagai jaringan penopang dan sawar terhadap trauma tajam, trauma tumpul, dan gigitan.

c) Lapisan subkutis/hypodermis

Lapisan subkutis/subkutan merupakan lapisan dibawah dermis terdiri dari lapisan lemak dan jaringan ikat yang banyak terdapat pembuluh darah dan saraf (8).

Fungsi kulit antara lain:

a) Fungsi termoregulasi

Panas tubuh tubuh dihasilkan dari aktivitas metabolic dan pergerakan otot. Panas seperti ini harus dikeluarkan atau subu tubuh akan naik di atas batas normal. Pada lingkungan suhu dingin panas harus dipertahankan atau suhu tubuh akan turun di bawah batas normal.

b) Fungsi proteksi

Kulit menjaga bagian dalam tubuh terhadap gangguan fisis (mis., gesekan, tarikan, gangguan kimiawi yang dapat menimbulkan iritasi, gangguan panas (mis., radiasi, sinar ultraviolet dan infeksi dari luar [bakteri, jamur]). Bantalan dermal di bawah kulit berperan sebagai pelindung terhadap ganggguan fisis.

c) Fungsi absorpsi

Kulit yang sehat tidak mudah menyerap air dan larut tetapi cairan yang mudah menguap lebih mudah diserap. Begitu juga yang larut dalam lemak. Permeabilitas kulit terhadap oksigen, karbon dioksida dan uap air memungkinkan kulit ikut mengambil bagian pada fungsi persepsi. Kemampuan absorpsi kulit memengaruhi tebal atau tipisnya kulit, hidrasi, kelembapan, dan metabolisme, penyerapan terjadi melalui celah antar-sel, menembus sel-sel epidermis, dan saluran kelenjar. 


\section{d) Fungsi ekskresi}

Kelenjar kulit mengeluarkan zat yang tidak berguna (zat sisa metabolisme) dalam tubuh berapa $\mathrm{NaCl}$, urea, asam urat, dan ammonia. Lapisan sebum berguna untuk melindungi kulit karena lapisan sebum mengandung minyak untuk melindungi kulit, menahan air yang berlebihan sehingga kulit tidak menjadi kering. Produksi kelenjar lemak dan keringat menyebabkan keasaman pada kulit.

e) Fungsi persepsi

Kulit mengandung ujung-ujung saraf ensorik di dermis dan subkutis untuk merangsang panas yang diterima oleh dermis dan subkutis. Sedangkan untuk rasangan dingin terjadi di dermis. Perbedaan dirasakan oleh papila dermis renvier yang terletak pada dermis, sedangkan tekanan dirasakan oleh epidermis serabut saraf sensorik yang lebih banyak jumlahnya di daerah erotic.

f) Fungsi pembentukan pigmen

Melanosit membentuk warna kulit. Enzim melanosom dibentuk alat golgi dengan bantuan tiroksinasi yang meningkatkan metabolisme sel, ion $\mathrm{Cu}$, dan oksigen. Sinar matahari memengaruhi melanosom, pigmen yang tersebar di epidermis melalu tangan-tangan dendrit, sedangkan lapisan di bawah oleh melanofag. Warna kulit tidak selamanya dipengaruhi oleh pigmen kulit melainkan juga oleh tebal/tipis kulit.

g) Fungsi keratinasi

Sel basal akan berpindah ke atas dan berubah bentuk menjadi sel spinosum. Makin ke atas sel ini semakin gepeng dan bergranula menjadi sel granulosum. Selanjutnya inti sel menghilang dan keratinosit menjadi sel tanduk yang amorf. Proses ini berlangsung terus menerus seumur hidup. Keratinosit melalui proses sintesis dan generasi menjadi lapisan tanduk yang berlangsung kira-kira 14-21 hari. Keratinin memberi perlindungan kulit terhhadap infeksi melalui mekanismes fisiologis.

h) Fungsi pembentukan vitamin D

Pembentukan vitamin D berlangsung dengan mengubah dihiroksi kolesterol dengan pertolongan sinar matahari. Kebutuhan vitamin tidak cukup hanya dari proses tersebut, pemberian vitamin D sistemik masih tetap diperlukan (9).

Luka adalah gangguan pada structural atau fisiologi integument yang membutuhkan respons perbaikan jaringan yang normal atau tidak normal. Semua luka dapat diklasifikasikan sebagai akut dan kronis. Luka akut merupakan proes penyembuhan tanpa komlikasi dalam kerangka waktu yang lazim, luka kronis adalah luka yang tidak sembuh dalam kerangka waktu yang diharapkan atau disertai dengan banyak komlikasi. Pada anak-anak, sebagian besar luka bersifat akut dan dapat dicegah (3) . Sedangkan luka insisi dapat disebabkan kecelakaan maupun karena perlakuan medis, contohnya operasi. Pada saat terjadi luka, tubuh secara normal berusaha memperbaiki jaringan yang rusak dengan cara menimbulkan respon terhadap cedera yang dikarakteristik adanya bengkak, kemerahan, panas, nyeri, dan kerusakan fungsi (4).

Luka adalah kerusakan kontinyuitas kulit, mukosa membran dan tulang atau organ tubuh yang lain. Ketika luka timbul, beberapa efek akan muncul seperti hilangnya seluruh atau sebagian fungsi organ, respon stress simpatis, perdarahan dan pembekuan darah, kontaminasi bakteri, dan kematian sel (10). Ketika luka timbul beberapa efek akan muncul :

a. Hilangnya seluruh atau sebagian fungsi organ

b. Respon stres simpatis

c. Pendarahan dan pembekuan darah

d. Konstaminasi bakteri

e. Kematian sel

Luka sering digambarkan berdasarkan bagaimana cara mendapatkan luka itu dan menunjukkan derajat luka (11).

1. Berdasarkan tingkat kontaminasi 
a. Clean Wounds (Luka bersih),

Luka bedah takterinfeksi yang mana tidak terjadi proses peradangan (inflamasi) dan infeksi pada sistem pernafasan, pencernaan, genital dan urinari tidak terjadi. Luka bersih biasanya menghasilkan luka yang tertutup; jika diperlukan dimasukkan drainase tertutup (misal; Jackson - Pratt). Kemungkinan terjadinya infeksi luka sekitar 1\% - 5\%.

b. Clean-contaminedWounds (Lukabersih terkontaminasi),

Merupakan luka pembedahan dimana saluran respirasi, pencernaan, genital atau perkemihan dalam kondisi terkontrol, kontaminasi tidak selalu terjadi, kemungkinan timbulnya infeksi luka adalah 3\% - 11\%.

c. Contamined Wounds (Luka terkontaminasi),

Termasuk luka terbuka, fresh, luka akibat kecelakaan dan operasi dengan kerusakan besar dengan teknik aseptik atau kontaminasi dari saluran cerna; pada kategori ini juga termasuk insisi akut, inflamasi nonpurulen. Kemungkinan infeksi luka 10\% - 17\%.

d. Dirty or Infected Wounds (Luka kotor atau infeksi),

Terdapatnya mikroorganisme pada luka.

Luka berdasarkan kedalaman dan luasnya luka antara lain: Stadium I : luka superfisial, yaitu luka yang terjadi pada lapisan epidermis kulit. Stadium II : Luka 'Partial Thicknees' yaitu hilangnya kulit keseluruhan sampai jaringan subkutan yang dapat meluas tetapi tidak mengenai otot. Stadium III : luka 'Full Thickness' yaitu hilangnya kulit keseluruhan sampai jaringan subkutan yang dapat meluas tetapi tidak mengenai otot. Stadium IV : luka 'Full Thickness' yang telah mencapai lapisan otot, tendon dan tulang dengan adanya destruksi/kerisakan yang luas (Maryunani, 2015).

Proses penyembuhan luka antara lain:

a) Reaksi segera

Segera setelah cedera, pembuluh darah berkontriksi di sekitar tempat tersebuh, dan vasokontriksi ini dapat mengurangi pendarahan dengan cepat. Kerusakan seluler menyebabkan keluarnya darah, dan hal ini membantu mengaktivasi koagulasi.

b) Inflamasi

Respon inflamasi akut terjadi beberapa jam setelah cedera, dan efeknya bertahan hingga 5-

7 hari. Kerusakan jaringan dan teraktivasinya factor pembekuan menyebabkan pelepasan berbagai substansi vasoaktif, seperti prostaglandin dan histamin, yang mengakibatkan peningkatan vasodilatasi dan peningkatan permeabilitas pembuluh darah, serta stimulasi serat-serat nyeri.

c) Profiliferasi

Selama fase profilerasi, pembentukan pembuluh darah yang baru berlanjut di sepanjang luka (angiogenesis atau neovaskularisasi). Proses ini sangat penting, karena tidak ada jaringan baru yang dapat dibentuk tanpa suplai oksigen dan nutrient yang dibawah oleh pembuluh darah yang baru.

d) Maturasi/remodeling

Bakuan fibrin awal digantikan oleh jaringan granulasi yang, setelah jaringan granulasi meluas hingga memeneuhi defek dan efek tertutupi oleh permukaan epidermal yang dapat bekerja dengan baik, mengalami remodeling. Hal ini biasanya terjadi kira-kira 20 hari setelah cedera, walaupun waktu tersebut bervariasi tergantung pada kondisi individu.

e) Parut

Remodeling jaringan granulasi mungkin menjadi factor contributor yang paling penting dalam perkembangannya masalah parut. Selama remodeling, densitas fibroblast menurun dan matang menjadi parut (12).

Juga dijelaskan dalam referensi lain tentang proses penyembuhan luka melalui empat tahap, yaitu :

a) Fase Koagulasi :

1) Trauma menyebabkan perdarahan dari pembuluh darah dan sistem limfatik yang rusak. 
2) Katekolamin menyebabkan terjadinya vasokontriksi langsung.

3) Komponen vasoaktif lain, seperti bradikinin, serotonin, dan histamin dikeluarkan dari sel mast jaringan.

4) Trombosit yang keluar memulai pembekuan darah di daerah trauma.

5) Trombosit menghasilkan faktor-faktor pembekuan yang menghasilkan fibrin, kemudian keduanya berperan dalam pembentukan mesh untuk migrasi lebih lanjut sel-sel inflamasi dan fibroblast.

6) Fibrin dihasilkan dari fibrinogen yang dikativasi oleh trombin yang diturunkan oleh precursor protrombin dengan adanya tromboplastin.

7) Jika mesh fibrin dihilangkan maka tidak ada lagi kekuatan jaringan.

8) Trombosit juga memegang peran penting karena merekalah sel pertama yang memproduksi beberapa sitokin esensial yang memulai sebagaian besar proses penyembuhan luka berikutnya.

b) Fase Inflamasi :

1) Fase inflamasi ditandai dengan migrasi berurutan ke dalam luka.

2) Dalam 24 jam pertama, luka diisi oleh lekosit PMN dan kemudian diikuti oleh makrofag.

3) Meskipun sel - sel inflamasi mengatur perbaikan matriks jaringan, ada 'pembawa pesan' regulasi yang sekarang telah dkenal sebagai sitokin yang dahulu dikenal sebagai growth factor.

c) Fase Fibroplasia :

1) Selama fase fibroplasia, terjadi proses penyembuhan yang paling penting.

2) Fibroplasia meningkatkan kekuatan luka, sehingga integritas jaringan dipulihkan.

3) Dalam 10 jam setelah trauma, terbukti terjadi peningkatan sintesis kolagen pada luka.

4) Puncaknya terjadi pada hari ke 5-7 dan kemudian menurun secara bertahap.

5) Pada saat ini juga terjadi produksi substansi dasar matriks dan poliferasi pembuluh darah.

d) Fase Remodeling :

1) Pada fase ini luka diperbaiki melalui proses pembentukan kembali.

2) Pada titik ini, sel radang akut dan kronik menghilang secara bertahap, angiogenesis menghilang, dan fibroplasia berakhir.

3) Keseimbangan antara pembentukan dan penghancuran kolagen secara bertahap dikembalikan.

4) Secara normal, perbaikan fibrosa masih tidak sempurna tetapi fungsional dan tidak berlebihan (8).

Proses penyembuhan luka dipengaruhi oleh beberapa faktor, yaitu

a) Pengaliran darah lokal. Ini harus seoptimal mungkin dalam proses penyembuhan yang baik;

b) Ada/tidak adanya edema. Adanya edema dapat menghalangi penyembuhan luka karena dengan demikian pengaliran darah akan berhenti;

c) Zat-zat pembakar dan pembangun. Zat-zat ini harus ada dalam kadar yang cukup dalam makanan yang dikonsumsi;

d) Kebersihan luka. Luka yang bersih akan lebih cepat sembuh daripada luka yang banyak nekrosisnya;

e) Besarnya luka. luka yang besar akan lebih cepat sembuh daripada luka yang kecil, dimana tepi luka itu berdekatan;

f) Kering atau tidaknya luka. Luka yang kering akan lebih cepat sembuh daripada luka yang basah, karena luka kering akan lebih cepat tumbuh lapisan granulasi dibawah keropeng luka (13).

Gel merupakan sistem semi padat yang terdiri dari suspense, dibuat dari partikel anorganik kecil atau molekul prganik besar terpenetrasi oleh suatu cairan. Jika massa gel terdiri dari jaringan partikel kecil yang terpisah, gel digolongkan sebagai sistem dua fase (misalnya Gel Aluminium Hidroksida). Gel fase tunggal terdiri dari makromolekul organic yang tersebar 
merata dalam terdispersi dalam cairan. Gel fase tunggal dapat dibuat dari makromolekul sintetik (misalnya karbomer) atau dari gona alam (misalya tragakan) (14).

1) Karakteristik Gel

Karakteristik atau sifat gel yaitu zat pembentuk gel yang ideal untuk sediaan farmasi dan kosmetik ialah inert, aman dan tidak bereksi dengan komponen lain. Pemilihan bahan pembentuk gel harus dapat memberikan bentuk padatan yang baik selama penyimpanan tapi dapat rusak segera ketika diberikan kekuatan atau daya yang disebabkan oleh pengocokan dalam botol, pemerasan tube, dan selama penggunaan topical. Gel dapat berbentuk melalui penurunan temperature, tetapi dapat juga pemebntukan gel terjadi setelah pemanasan tube, atau selama penggunaan topical. Gel dapat terbentuk melalui penurunan temperature, tetapi dapat juga pembentukan gel terjadi setelah pemanasan terjadi setelah pemanasan pada suhu tertentu. Penggunaan bahan pembentuk gel yang kosentrasinya sangat tinggi atau BM besar menghasilkan gel yang sulit dikeluarkan atau digunakan karakteristik gel harus sesuai dengan tujuan penggunaan sediaan yang diharapkan (15).

2) Bahan-bahan pembentuk gel

Polimer-polimer yang biasa digunakan untuk membuat gel-gel farmasetik meliputi gom alam, tragakan, pectin, karagen, agar, asam alginate, serta bahan-bahan sintesis dan semisinesis seperti metil selulosa. Hidroksetilsellosa,karboksimetilselulosa, dan karbopol yang merupakan vinil sintesis dengan gugus karboksil yang terionisasi (16).

3) Dasar gel yang umum digunakan adalah gel hidrofobik dan gel hidrofilik

a) Dasar gel hidrofobik

Dasar gel hidrofobik terdiri dari partakel-partikel anorganik, apabila ditambahkan kedalam fase pendispersi, hanya sedikit sekali interaksi antar kedua fase. Berbeda dengan bahan hidrofolik, bahan hidrofobik tidak secara spontan menyebar, tetapi harus dirangsang dengan prosedur yang khusus (15).

b) Dasar gel hidrofolik

Dasar gel hidrofolik terdiri dari molekul-molekul anorganik yang besar dan dapat dilarutkan dengan molekul dari fase pendispersi. Istilah hidrofilik berarti suka pada pelarut. Pada umumnya karena daya Tarik menarik pada pelarut dari bahan-bahan hidrofilik kebalikan dari tidak adanya daya tarik menarik dari bahan hidrofobik, system koloidhidrofilik biasanya lebih mudah untuk dibuat dan memiliki stabilitas yang lebih besar (Ansel, 2008). Basis gel hidrofilik antara lain bentonit, tragakan, derivate selulosa karbomer/karbopol, polovinil alcohol, alginate (17). Gel hidrofilik umumnya mengandung komponen bahan pengembang, air, penahan lembab dan bahan pengawet (17).

c) Keuntungan gel Hidrofilik

Keuntungan gel hidrofilik antara lain, daya sebarnya pada kulit baik, efek dingin, tidak lengket, mudah mengering, tidak menhambat fungsi fisiologi kulit, tidak menyumbat poripori kulit, mudah dicuci dengan air dan memungkinkan pemakaian pada bagian tubuh yang berambut, dan pelepasan obatnya baik (17).

\section{Metode Penelitian}

Jenis penelitian ini adalah eksperimental laboratorium yang bertujuan untuk memperhatikan perubahan diameter luka insisi dan lama penyembuhannya luka. menggunakan gel ekstrak daun binahong (Anredera ardifolia (Ten). Steenis) pada hewan uji Tikus Wistar Jantan.

Alat yang digunakan dalam penelitian ini yaitu batang pengaduk, gelas ukur, cawan porselin, pipet tetes, timbangan analitik, pisau bedah steril, gunting stainless, penangas air, jangka sorong, lumpang dan alu.

Bahan yang digunakan yaitu hewan tikus wistar jantan etanol 96\%, ekstrak daun binahong (Anredera cordifolia), HPMC, propilenglikol, natrium benzoat, gliserin, air suling. 
a. Populasi, populasi yang digunakan adalah semua tanaman daun binahong (Anredera Cordifolia) yang ada di dusun Suli, Kabupaten Tana Toraja.

b. Sampel yang digunakan dalam penelitian ini adalah daun binahong (Anredera cordifolia) yang di ambil dari dusun Suli, Kabupaten Tana Toraja.

Tahap awal pengambilan sampel merupakan tahap yang paling penting dikarenakan kesalahan awal dalam pengambilan dapat merusak sampel ataupun kandungan di dalamnya yang dapat menyebabkan pengerjaan pada tahap-tahap selanjutnya menjadi percuma. Dalam pengambilan bahan alam diperlukan sebuah cara khusus karena sampel yang akan diambil memiliki sifat yang berbeda dengan sampel lainnya, begitu pula mengenai waktu pengambilannya dan alat yang yang digunakan pada saat pengambilan serta cara pengolahannya setelah masa pengumpulan/panen telah dilakukan.

Prosedur kerja

a. Pengolahan sampel

Sampel yang diperoleh dibersihkan dari kotoran-kotoran kemudian dicuci bersih dengan air mengalir selama 2 kali lalu ditiriskan, keringkan ditempat yang teduh tanpa terkena sinar matahari langsung sampai sampel tersebut benar-benar kering, daun binahong yang sudah kering dihaluskan kemudian di maserasi dengan pelarut etanol 96\%.

\section{b. Ekstraksi daun binahong}

Sebanyak 5000 gram daun binahong, dimasukkan kedalam bejana, kemudian ditambahkan etanol 96\% sebanyak $1500 \mathrm{ml}$ hingga sampel terendam, wadah maserat ditutup dan disimpan ditempat terlindung dari cahaya matahari langsung sambil sesekali diaduk. Pengantian penyari dilakukan tiga kali sehari sekali dengan jumlah penyari yang sama yaitu $1500 \mathrm{ml}$. pengantian cairan dilakukan sebanyak 2 kali selama 6 hari. Ekstrak etanol 96\% yang didapatkan dikumpulkan dan diuapkan cairan penyarinya hingga diperoleh ekstrak kental.

c. Pembuatan gel dan formulasi

Tabel 1. Formulasi gel ekstrak daun binahong

\begin{tabular}{|c|c|c|c|c|c|}
\hline \multicolumn{6}{|c|}{ Konsentrasi (\%) } \\
\hline Bahan & Kegunaan & F I & F II & F III & F IV \\
\hline $\begin{array}{l}\text { Ekstrak } \\
\text { Daun } \\
\text { Binahong }\end{array}$ & Zat aktif & 5 & 10 & 15 & - \\
\hline HPMC & Basis gel & 2 & 2 & 2 & 2 \\
\hline $\begin{array}{l}\text { Natrium } \\
\text { Benzoate }\end{array}$ & Pengawet & 0,5 & 0,5 & 0,5 & 0,5 \\
\hline \multirow{2}{*}{$\begin{array}{l}\text { propilenglikol } \\
\text { Gliserin }\end{array}$} & Kosolven & 10 & 10 & 10 & 10 \\
\hline & $\begin{array}{l}\text { Humektan } \\
\text { Emolien }\end{array}$ & 10 & 10 & 10 & 10 \\
\hline Air suling & Pelarut & \multicolumn{4}{|c|}{ Ad $100 \mathrm{ml}$} \\
\hline
\end{tabular}

F I: Formula gel dengan konsentrasi ekstrak sebanyak $5 \%$

F II : Formiula gel dengan konsentrasi ekstrak sebanyak $10 \%$

F III : Formula gel dengan konsentrasi ekstrak sebanyak $15 \%$

FIV : Formula gel tanpa mengandung ekstrak 
d. Pembuatan sediaan gel ekstrak daun binahong

Disiapkan semua bahan yang digunakan. Bahan ditimbang sesuai dengan formula yang ada. Gel dibuat dengan cara HPMC didespersikan kedalam air panas kemudian dihomogenkan, ditambah natrium benzoate, digerus hingga homogeny pada wadah yang berbeda ekstrak daun binahong dilarutkan dengan gliserin kemudian ditambahkan propilenglikol dihomogenkan kembali, wadah yang berisi campuran ekstrak daun binahong dicampur dengan basis HPMC yang telah dibuat, dihomogenkan kembali hingga berbentuk massa gel.

\section{Hasil Penelitian}

1. Hasil Maserasi Daun Binahong (Anredera Cordifolia)

Tabel 1. Hasil Maserasi

Sampel

Simplisia Daun Binahong

(Anredera Cordifolia)

Ekstrak kental daun binahong

(Anredera Cordifolia)

2. Data hasil pengukuran panjang luka jumlah (gram)

$500 \mathrm{gr}$

Tabel 2. Hasil pengukuran panjang luka

\begin{tabular}{|c|c|c|c|c|c|}
\hline Hari ke & $\begin{array}{c}\text { KI } \\
(\mathbf{5 \%})\end{array}$ & $\begin{array}{c}\text { KII } \\
(10 \%)\end{array}$ & $\begin{array}{c}\text { KIII } \\
(15 \%)\end{array}$ & $\begin{array}{c}\text { KIV } \\
\text { (basis) }\end{array}$ & $\begin{array}{c}\mathrm{KV} \\
\text { (Bioplacenton) }\end{array}$ \\
\hline 1 & $3 \mathrm{~cm}$ & $3 \mathrm{~cm}$ & $3 \mathrm{~cm}$ & $3 \mathrm{~cm}$ & $3 \mathrm{~cm}$ \\
\hline 2 & $3 \mathrm{~cm}$ & $3 \mathrm{~cm}$ & $2,9 \mathrm{~cm}$ & $3 \mathrm{~cm}$ & $3 \mathrm{~cm}$ \\
\hline 3 & $2,9 \mathrm{~cm}$ & $2,6 \mathrm{~cm}$ & $2,3 \mathrm{~cm}$ & $3 \mathrm{~cm}$ & $2,7 \mathrm{~cm}$ \\
\hline 4 & $2,7 \mathrm{~cm}$ & $2,2 \mathrm{~cm}$ & $2,1 \mathrm{~cm}$ & $2,9 \mathrm{~cm}$ & $2,4 \mathrm{~cm}$ \\
\hline 5 & $2.5 \mathrm{~cm}$ & $1,6 \mathrm{~cm}$ & $1,3 \mathrm{~cm}$ & $2,7 \mathrm{~cm}$ & $1,9 \mathrm{~cm}$ \\
\hline 6 & $2,2 \mathrm{~cm}$ & $1,3 \mathrm{~cm}$ & $1,0 \mathrm{~cm}$ & $2,7 \mathrm{~cm}$ & $1,4 \mathrm{~cm}$ \\
\hline 7 & $1,8 \mathrm{~cm}$ & $0,7 \mathrm{~cm}$ & $0,4 \mathrm{~cm}$ & $2,5 \mathrm{~cm}$ & $0 \mathrm{~cm}$ \\
\hline 8 & $1,3 \mathrm{~cm}$ & $0,5 \mathrm{~cm}$ & $0 \mathrm{~cm}$ & $2,0 \mathrm{~cm}$ & $0 \mathrm{~cm}$ \\
\hline 9 & $0,8 \mathrm{~cm}$ & $0 \mathrm{~cm}$ & $0 \mathrm{~cm}$ & $1,9 \mathrm{~cm}$ & $0 \mathrm{~cm}$ \\
\hline 10 & $0,4 \mathrm{~cm}$ & $0 \mathrm{~cm}$ & $0 \mathrm{~cm}$ & $1,6 \mathrm{~cm}$ & $0 \mathrm{~cm}$ \\
\hline 11 & $0 \mathrm{~cm}$ & $0 \mathrm{~cm}$ & $0 \mathrm{~cm}$ & $1,2 \mathrm{~cm}$ & $0 \mathrm{~cm}$ \\
\hline 12 & $0 \mathrm{~cm}$ & $0 \mathrm{~cm}$ & $0 \mathrm{~cm}$ & $0,6 \mathrm{~cm}$ & $0 \mathrm{~cm}$ \\
\hline
\end{tabular}




\begin{tabular}{cccccc}
\hline 13 & $0 \mathrm{~cm}$ & $0 \mathrm{~cm}$ & $0 \mathrm{~cm}$ & $0,2 \mathrm{~cm}$ & $0 \mathrm{~cm}$ \\
\hline 14 & $0 \mathrm{~cm}$ & $0 \mathrm{~cm}$ & $0 \mathrm{~cm}$ & $0 \mathrm{~cm}$ & $0 \mathrm{~cm}$
\end{tabular}

3. Hasil uji efektivitas penyembuhan luka insisi gel ekstrak daun binahong (Anredera Cordifolia) yang di sajikan dalam analisis statistik Anova secara SPSS.

\section{Descriptives}

Penyembuhan

\begin{tabular}{|c|c|c|c|c|c|c|c|c|}
\hline & \multirow[b]{2}{*}{$\mathrm{N}$} & \multirow[b]{2}{*}{ Mean } & \multirow[b]{2}{*}{$\begin{array}{c}\text { Std. } \\
\text { Deviation }\end{array}$} & \multirow[b]{2}{*}{$\begin{array}{l}\text { Std. } \\
\text { Error }\end{array}$} & \multicolumn{2}{|c|}{$\begin{array}{l}\text { 95\% Confidence } \\
\text { Interval for Mean }\end{array}$} & \multirow[b]{2}{*}{$\begin{array}{c}\text { Minim } \\
\text { um }\end{array}$} & \multirow[b]{2}{*}{$\begin{array}{c}\text { Maxim } \\
\text { um }\end{array}$} \\
\hline & & & & & $\begin{array}{l}\text { Lower } \\
\text { Bound }\end{array}$ & $\begin{array}{l}\text { Upper } \\
\text { Bound }\end{array}$ & & \\
\hline $\mathrm{KI}$ & 14 & 1,5000 & 1,21132 & 32374 & ,8006 & 2,1994 & 00 & 3,00 \\
\hline KII & 14 & 1,1250 & 1,16697 & 31189, & ,4512 & 1,7988 & 00 & 3,00 \\
\hline KIII & 14 & 1,0143 & 1,14058 & 30483 & ,3557 & 1,6728 & 00 & 3,00 \\
\hline KIV & 14 & 1,8286 & 1,22878 & 32840 & 1,1191 & 2,5380 & 00 & 3,00 \\
\hline KV & 14 & 1,2429 & 1,23333 & 32962 & ,5308 & 1,9550 & ,00 & 3,00 \\
\hline Total & 70 & 1,3421 & 1,19818 & 14321 & 1,0564 & 1,6278 & 00 & 3,00 \\
\hline
\end{tabular}

Test of Homogeneity of Variances

Penyembuhan

\begin{tabular}{|r|r|r|r|}
\hline $\begin{array}{c}\text { Levene } \\
\text { Statistic }\end{array}$ & df1 & df2 & \multicolumn{1}{c|}{ Sig. } \\
\hline, 131 & 4 & 65 &, 971 \\
\hline
\end{tabular}

Jadi, Homogen karena nilai sig >0,05

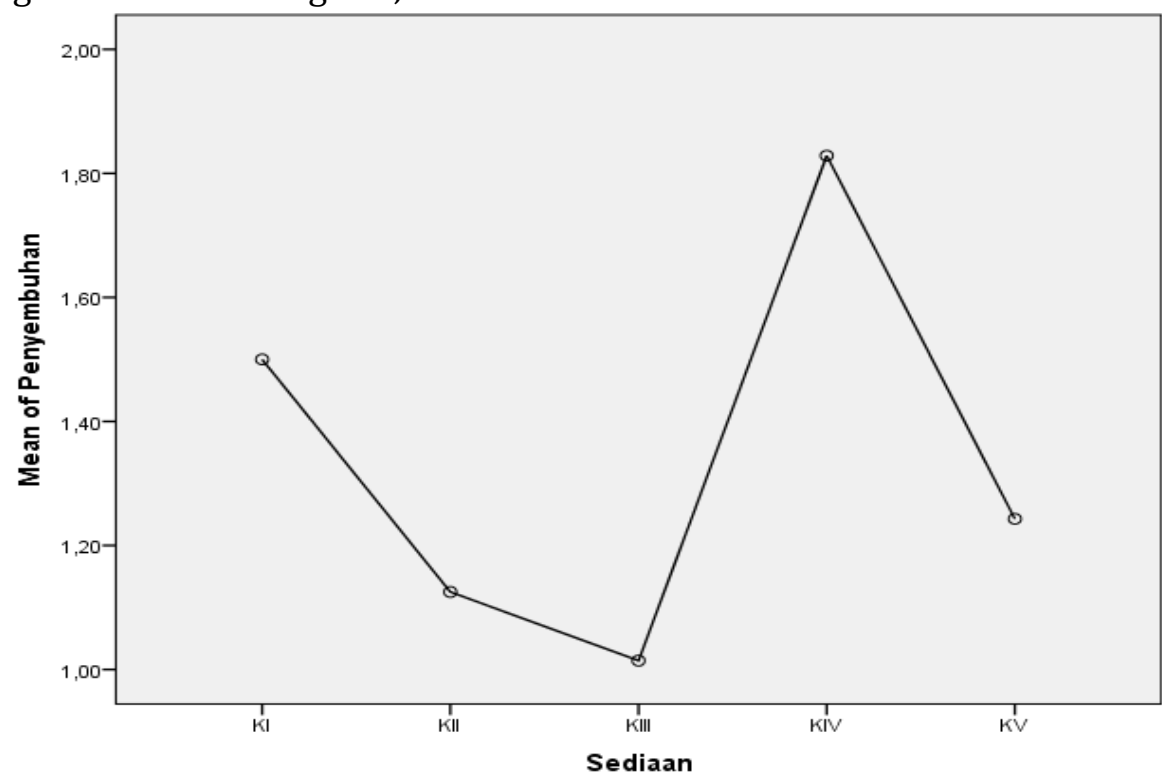

\section{Diskusi}

Pada penelitian ini digunakan ekstrak kental daun binahong (Anredera Cordifolia) yang diperoleh dengan cara mengekstraksi 500 gram serbuk daun binahong di ekstraksi 
menggunakan metode maserasi. Serbuk daun binahong (Anredera Cordifolia) dimaserasi menggunakan etanol 96\% sampai seluruh sampel terendam sempurna. Ditutup rapat dan didiamkan selama 24 jam ditempat gelap sambil beberapa kali dilakukan pengadukan, lalu disaring, residu dimaserasi kembali dan dilakukan sebanyak 3 kali. Maserat berupa ekstrak cair yang didapat dikumpulkan dalam satu wadah kemudian diuapkan dengan cara dianginanginkan sampai pelarut habis menguap hingga didapat ekstrak kental daun binahong (Anredera Cordifolia). Simplisia dihaluskan sesuai dengan persyaratan farmakope (umumnya dipotong-potong atau sering diserbuk kasar) disatukan dengan bahan ekstraksi, disimpan ditempat yang terlindungi dari cahaya langsung untuk mencegah rekasi yang di katalisis cahaya atau perubahan warna lalu di kocok kembali. Waktu maserasi adalah berbeda-beda, masingmasing farmakope mencantumkan 4-10 hari, kira-kira 5 hari menurut pengalaman yang sudah memadai, diperas dengan kain pemeras (17).

Proses ekstraksi sampel dilakukan dengan cara maserasi. proses ini dipilih karena relatif sederhana, tidak memerlukan peralatan khusus dan tidak memerlukan panas sehingga penguraian senyawa yang tidak tahan pemanasan dapat dicegah. Maserasi dilakukan menggunakan etanol 96\% karena etanol merupakan penyari yang bersifat universal yaitu dapat melarutkan. Etanol 96\% yang tidak banyak mengandung air dibandingkan etanol 70\% sehingga resiko ekstrak ditumbuhinya jamur atau kapang lebih kecil. Etanol 96\% juga dipilih karena senyawa yang terkandung pada daun binahong yaitu : Tanin, saponin, dan flavonoid. Penelitian ini bertujuan untuk mengetahui efektivitas sediaan gel ekstrak daun binahong sebagai obat luka insisi terhadap hewan uji tikus wistar jantan. Uji ini dilakukan untuk mencegah terjadinya efek samping terhadap kulit pada sediaan kosmetik sebelum dijual ke masyarakat umum dan untuk menentukan potensi sediaan gel pada kulit setelah diberikan, sehingga dapat diketahui tingkat keamanan dari sediaan gel yang dihasilkan.

Pada penelitian ini zat aktif yang digunakan adalah ekstrak daun Binahong dimana ekstrak tersebut digunakan sebagai antibakteri karena mengandung flavonoid yang mana merupakan senyawa yang mempunyai sifat antibakteri terhadap bakteri gram positif dan golongan coccus. Flavonoid merupakan senyawa yang mudah larut dalam air. Kelarutannya dalam air dapat diekstraksi dengan etanol 96\%. Pilihan pelarut etanol karena dapat menarik sejumlah senyawa tanaman yang sifatnya polar, dan etanol 96\% digunakan karena mudah menguap, kadar air yang tertinggal pada ekstrak sangat kecil. Potensi daun Binahong sebagai tanaman obat dapat ditingkatkan dengan mengubah bentuknya menjadi sediaan yang lebih praktis seperti sediaan gel.

Gel adalah sediaan semipadat yang terdiri dari suspensi yang dibuat dari partikel anorganik yang kecil atau molekul organik yang besar terpenetrasi oleh suatu cairan. Sediaan gel dipilih karena mudah mengering, membentuk lapisan film yang mudah dicuci dan memberikan rasa dingin di kulit. Sediaan gel ini dibuat dengan menggunakan zat tambahan antara lain HPMC (Hidroxy prophyl metil cellulose) yang berfungsi sebagai basis gel. HPMC digunakan sebagai basis gel karena sering digunakan dalam sediaan kosmetik dan obat, karena dapat menghasilkan gel yang bening, mudah larut dalam air dan mempunyai ketoksikan yang rendah. Selain itu HPMC bersifat netral, mempunyai pH yang stabil antara 3 - 11, tahan terhadap asam basa, sebagai antimikroba dan tahan panas. HPMC juga memiliki kecepatan pelepasan yang baik dan daya sebarnya luas. Golongan natrium benzoat yang berfungsi sebagai pengawet karena sediaan gel memiliki kandungan air tinggi yang dapat menyebabkan terjadinya kontaminasi mikroba. Propilen glikol $\left(\mathrm{C}_{3} \mathrm{H}_{8} \mathrm{O}_{2}\right)$ berfungsi sebagai kosolven. Gliserin untuk menjaga kestabilan sediaan gel dengan cara mengabsorbsi kelembaban dan mengurangi penguapan air dari sediaan. Bahan Trietanolamin yang bersifat basa untuk menetralkan sifat asam dari HPMC dan juga untuk meningkatkan kejernihan HPMC.

Pembuatan gel ini dibuat sebanyak lima sediaan yang terdiri dari kontrol yang dibuat tanpa menggunakan ekstrak dan sediaan yang kedua dibuat dengan zat aktif ekstrak daun binahong 
dengan konsentrasi 5\%, formula yang ketiga dengan konsentrasi ekstrak 10\% dan formula keempat dengan ekstrak konsentrasi 15\% dengan menggunakan zat tambahan yang sama.

Sediaan gel ekstrak daun binahong diberikan pada uji luka insisi hewan uji tikus wistar jantan. Uji luka insisi pada hewan coba menggunakan 12 ekor tikus wistar jantan. Tahapan uji pada luka insisi yaitu dengan mencukur bulu punggung hewan uji tikus wistar jantan dengan ukuran $2 \mathrm{~cm}$ pada semua kelompok hewan uji. Setelah dicukur bagian tersebut diberi perlukaan sepanjang $2 \mathrm{~cm}$ pada epidermis. Luka yang terjadi diolesi dengan sediaan uji \pm 1 gram setiap 24 jam, kemudian ditutup dengan kain kasa, dibuka, panjang luka diukur kemudian ditutup kembali dengan kain kasa dilakukan sampai luka sembuh, dicatat hari mulai menurunnya panjang luka, pembentukan maturasi dan hari luka tertutup 100\%. Pengukuran efek penyembuhan luka dilakukan berdasarkan profil penyembuhan luka yaitu pembentukan maturasi, waktu penutupan luka dan penurunan panjang luka

Selama 24 jam, diberi perlakuan 3 kali sehari pada luka insisi hewan uji yang ditutup dengan kasa perban dan diplester untuk menghindari terjadinya kerusakan zat uji akibat kontaminasi mikroorganisme. Setiap hari dilakukan pengamatan panjang luka dengan mengukur menggunakan penggaris, dilihat perubahan proses penyembuhan luka. Hal ini dilakukan selama 14 hari.

Setelah pemaparan sediaan uji selama 14 hari, berdasarkan data hasil penelitian pemberian sediaan gel ekstrak daun Binahong terhadap luka insisi tikus wistar jantan dapat dilihat bahwa pada perlakuan pertama untuk basis (kontrol) memberikan hasil selama 13 hari mengalami perlukaan dan hari keempat belas terjadi penutupan, sedangkan untuk pemberian ekstrak dengan konsentrasi 5\% hanya selama 10 hari memberikan efek inflamasi. Pada hari ke sebelas mengalami maturasi yang ditandai dengan penutupan luka secara keseluruhan. Pada pemberian formula dengan konsentrasi, $10 \%$ terjadi penutupan luka pada hari kesembilan dan pada konsentrasi $15 \%$ proses penutupan luka terjadi pada hari kedelapan. Pengamatan penyembuhan luka ditandai dengan terjadinya penutupan luka secara menyeluruh pada bagian kulit yang berawal adanya inflamasi kemudian disusul dengan proses proliferasi dan akhirnya terjadi maturasi atau remodeling. Perlakuan pada control positif yang menggunakan sediaan bioplasenton, mengalami penutupan luka yang cepat dibandingkan dengan keempat formula yang lain.

Penyembuhan luka adalah panjang waktu proses pemulihan pada kulit karena adanya kerusakan atau disintegritas jaringan kulit. Luka merupakan adalah terputusnya kontinuitas suatu jaringan oleh karena adanya cedera atau pembedahan. Bentuk dari luka berbeda tergantung penyebabnya, ada yang terbuka dan tertutup. Salah satu contoh luka terbuka adalah insisi/luka sayat dimana terdapat robekan linier pada kulit dan jaringan di bawahnya. Luka sayat adalah luka yang terjadi karena teriris oleh instrumen yang tajam (18).

Berdasarkan hasil penelitian untuk luka tertutup $100 \%$ pada penggunaan masing-masing formula juga menunjukkan perbedaan waktu. Hal ini terlihat dari hasil analisis statistik Anova secara SPSS hubungan antara formula dan kecepatan luka tertutup $100 \%$, di mana $\mathrm{F}_{\text {hitung }}>\mathrm{F}_{\text {tabel }}$ pada taraf kepercayaan $5 \%$ dan $1 \%$, ini berarti terdapat perbedaan waktu penyembuhan luka $100 \%$ yang sangat berbeda nyata/sangat signifikan dari penggunaan masing-masing formula. Untuk gel Bioplacenton ${ }^{\circledR}$ masih lebih cepat dibandingkan dengan gel ekstrak daun binahong.

Dari hasil analisis diatas, dapat disimpulkan bahwa formula gel ekstrak etanol daun Binahong mempunyai efektivitas dalam menyembuhkan luka insisi atau sayat pada tikus wistar jantan dan efek penyembuhan luka sayat yang optimum diberikan oleh sediaan gel dengan kandungan ekstrak etanol daun binahong sebesar $15 \%$.

\section{Kesimpulan}

Berdasarkan hasil penelitian yang telah dilakukan maka dapat disimpulkan bahwa Formula gel ekstrak etanol daun Binahong (Anredera Cordifolia) konsentrasi 5\%, 10\%, dan 15\% memiliki efektivitas dalam menyembuhkan luka insisi pada tikus wistar jantan dengan lama 
penyembuhan kurang dari 14 hari. Namun konsentrasi optimum ekstrak daun binahong (Anredera Cordifolia) yang dapat menyembuhkan luka insisi pada tikus wistar jantan dalam bentuk sediaan gel adalah sebesar $15 \%$.

\section{Daftar Pustaka}

1. Efendi Fery, Citrareksoko Padmono, Subagyo Deo, 2016. Efektifitas Salep Ekstrak Daun Etanol Daun Binahong (Anredera Cordifolia (Teen).Steenis). Sekolah Tinggi Teknologi Industri Dan Farmasi Bogor.

2. Afin and Friends. 2016. Daun Dahsyat Pencegah dan Penyembuh Penyakit; AR-RUZZ Media, Jogjakarta.

3. Wong L, Donna, Eaton-Hockenberry Marilya, Wilson David, Winkelstein L. Marilyn, Schwartz Patricia. 2008. Buku aJar Keperawatan Pediatrik. Jakarta : EGC.

4. Aprilia, R.C., 2018, Pengaruh pemberian salep ekstrak ampas apel manalagi (Maulus Sylvestris Mill) terhadap ekspresi IL-6 dan jumlah sel radang sebagai penyembuhan luka insisi pada Hewan coba tikus (Rattus Novergicus). Universitas Brawijaya. Malang

5. Fajrina Aulia., 2017. Formulasi Sediaan Gel Ekstrak Etanol Jambul Bol (Syzgium Mallacense Merr \& Perry) Sebagai Pengobatan Luka Sayat. Universitas Sumetera Utara. Medan

6. Wahyuni Dwi Kusuma, Ekasari Wiwied, Wisono Ridho Joko, Purnobasuki Hery. 2016. TOGA INDONESIA. Airlangga University Press.

7. Hariana, H.A. 2013. Tumbuhan Obat dan khasiatnya, penebar wadaya, Jakarta.

8. Maryunani, anik. S.Kep.Ns, ETN. 2015. Perawatan luka modern (modern woundcare) terkini dan terpercaya. IN MEDIA Perpustakan nasional jakarta.

9. Syaifuddin H. 2017. Anatomi Fisiologi Manusia. Penerbit Buku kedokteran; EGC

10. Stevens P.J.M, Bordui.F, Wedye der van J.A.G. 1997. Ilmu Keperawatan. Penerbit Buku Kedokteran: EGC

11. Direktorat jendral POM, 1995. Farmakope Indonesia edisi IV. Departemen Kesehatan RI: Jakarta

12. Ansel H, C., 1989. Pengantar Bentuk Sediaan Farmasi. Edisi IV. Diterjemahkan Oleh Ibrahim, F., Universitas Indonesia Press. Jakarta.

13. Lachman L.,Liberman HA \& Kaning JL. 2008. Teori dan praktek farmasi Industry. Universitas Indonesia. Jakarta. 